University of Nebraska - Lincoln

DigitalCommons@University of Nebraska - Lincoln

\title{
Dry Weight and Nitrogen Content of Chickpea and Winter Wheat Grown in Pots for Three Rotations
}

James E. Bidlack

University of Central Oklahoma, jbidlack@ucok.edu

Charles T. Mackown

USDA-ARS

Srinivas C. Rao

USDA-ARS

Follow this and additional works at: https://digitalcommons.unl.edu/usdaarsfacpub

Part of the Agricultural Science Commons

Bidlack, James E.; MacKown, Charles T.; and Rao, Srinivas C., "Dry Weight and Nitrogen Content of Chickpea and Winter Wheat Grown in Pots for Three Rotations" (2007). Publications from USDA-ARS / UNL Faculty. 569.

https://digitalcommons.unl.edu/usdaarsfacpub/569

This Article is brought to you for free and open access by the U.S. Department of Agriculture: Agricultural Research Service, Lincoln, Nebraska at DigitalCommons@University of Nebraska - Lincoln. It has been accepted for inclusion in Publications from USDA-ARS / UNL Faculty by an authorized administrator of DigitalCommons@University of Nebraska - Lincoln. 


\title{
Dry Weight and Nitrogen Content of Chickpea and Winter Wheat Grown in Pots for Three Rotations
}

\author{
James E. Bidlack, ${ }^{1}$ Charles T. MacKown, ${ }^{2}$ and Srinivas C. Rao ${ }^{2}$ \\ ${ }^{1}$ Department of Biology, University of Central Oklahoma, Edmond, Oklahoma, USA \\ ${ }^{2}$ USDA-ARS Grazinglands Research Laboratory, El Reno, Oklahoma, USA
}

\begin{abstract}
Chickpea [Cicer arietinum (L.)] cultivars 'ICCV-2' and 'Sarah' were studied along with a control, multistrain, TAL 1148, and TAL 480 Bradyrhizobium strains to determine the effect(s) of cultivar and inoculum on dry weight (DW) and nitrogen $(\mathrm{N})$ content of the legume, as well as soil mineral N, DW, and N content of wheat [Triticum aestivum (L.) emend. Thell.] in a continuous wheat-legume rotation. Chickpeas were planted during the summer and harvested in the fall of 1992, 1993, and 1994. Vegetative growth from chickpeas was incorporated into the soil prior to wheat planting, and soil cores were taken at 35 to $48 \mathrm{~d}$ after chickpea harvests. Additional summer fallow treatments for the winter wheat part of the experiment received 0,45 , and $90 \mathrm{~kg} \mathrm{~N} \mathrm{ha}^{-1}$ each year. Wheat plants were removed the following spring and stubble was incorporated into the soil before planting chickpeas in the summer. 'Sarah' chickpeas accumulated about the same or more shoot DW and shoot N compared to 'ICCV-2'; whereas 'ICCV-2' generally produced more pod DW and pod N compared to 'Sarah.' Inoculum had no significant effect on chickpea DW or N content. Wheat DW and $\mathrm{N}$ following legumes increased marginally after growing 'Sarah' chickpeas, as evidenced by higher values of some treatments. Only the multistrain or absence of inoculum in 'Sarah' chickpeas resulted in significantly greater wheat DW or $\mathrm{N}$ content compared to the fallow wheat receiving no added $\mathrm{N}$ fertilizer. The contributions from 'ICCV-2' chickpeas to wheat DW and $\mathrm{N}$ content were not significant. Soil mineral $\mathrm{N}$, as well as wheat DW and $\mathrm{N}$ content, fluctuated or increased during this three-year study, which demonstrated some benefit from incorporation of chickpeas into a wheat-legume cropping system.
\end{abstract}

Keywords: Cicer arietinum, cropping system, legume, nitrogen fixation, soil, wheat

Received 5 July 2006; accepted 2 December 2006.

Address correspondence to J. E. Bidlack, Department of Biology, University of Central Oklahoma, 100 N. University Dr., Edmond, OK 73034, USA. E-mail: jbidlack@ucok. edu 


\section{INTRODUCTION}

Chickpeas [Cicer arietinum (L.)] rank among the top three grain legumes grown in the world, with about 8 million metric tons produced in 2000 (McNew, 2001). The United States contributes less than one percent of this amount (59,330 metric tons in 2000; as cited by Smith and Jimmerson, 2005), although increasing domestic and global demands for this crop have maintained a viable market for chickpeas for some time (Auld et al., 1982). As long as market demands remain stable or increase, there will be a continued need for this legume and the potential to include chickpeas as part of cropping systems in the United States.

Incorporation of chickpeas into a wheat [Triticum aestivum (L.) emend. Thell.]-legume rotation of the southern Great Plains has potential because of the ability of this legume to persist during dry, hot, fallow periods (Saxena, 1987) such as that encountered after winter wheat. In addition to enriching soil fertility through nitrogen $\left(\mathrm{N}_{2}\right)$ fixation, chickpeas, like other legumes, may provide U.S. farmers with an alternative cash crop, control soil erosion, increase soil organic matter and provide new management strategies for pest control during the summer (Lal et al., 1991). Previous investigations in other parts of the world have shown that use of different chickpea cultivars (Beck, 1992) and (Brady) Rhizobium strains (Somasegaran et al., 1988) can improve yield and $\mathrm{N}_{2}$ fixation of chickpea. Before agronomists in the U.S. can effectively include chickpea in wheat-legume cropping systems of the southern Great Plains, it will be necessary to evaluate cultivars and inoculum strains for optimum performance. In this study, chickpeas were grown outdoors in pots to simulate a wheat-legume cropping system in Oklahoma. Chickpea cultivar and inoculum strains were evaluated to determine the effect(s) of cultivar, Bradyrhizobium strain, environment (as influenced by year to year variation), and interactions thereof, on dry weight (DW) and nitrogen content of chickpeas as well as soil mineral nitrogen, DW, and nitrogen of wheat following chickpeas. Summer fallow periods followed by winter wheat were also compared with chickpeawheat rotations to determine any benefit(s) this cropping system might provide to winter wheat.

\section{MATERIALS AND METHODS}

Chickpea and wheat plants were established and maintained in clay pots on the roof of the science building at the University of Central Oklahoma (UCO) in Edmond, Oklahoma from June 1992 through July 1995. Laboratory analyses took place at UCO and the USDA-ARS Grazinglands Research Laboratory in El Reno, Oklahoma. Chickpeas were grown during summer and harvested in late summer/early fall of 1992, 1993, and 1994; and were followed by winter wheat harvested in spring 1993, 1994, and 1995. All plants were grown in $36 \mathrm{~cm}$ diameter clay pots with a capacity of $20 \mathrm{~L}$ containing a 50:50 mixture of Fafard 
Soil Mix No. 2 (Fafard Soil Company, Quebec, Canada ${ }^{1}$ ) and Dale silt loam (fine-silty, mixed, thermic Pachic Haplustoll) with a $\mathrm{pH}$ of 6.6. About $3 \mathrm{~L}$ of the same soil mix were added to each pot after wheat harvest to compensate for soil samples removed the previous year.

Early-maturing chickpea cultivars 'ICCV-2' and 'Sarah' were obtained from germplasm collections of the International Crop Research Institute for Semi-Arid Tropics at Patancheru, India, and Washington State University, Pullman, Washington, respectively. The 'ICCV-2' cultivar (flowers at 30 to $35 \mathrm{~d}$; Kumar et al., 1985) was chosen to represent a white-seeded, Kabuli-type chickpea; whereas the 'Sarah' cultivar (flowers at $56 \mathrm{~d}$; Muehlbauer and Kaiser, 1991) was chosen to represent a dark-seeded, Desi-type chickpea. The wheat cultivar TAM 101 was used throughout the experiment and was obtained from Ross Seed Company, El Reno, Oklahoma.

Two distinct strains of chickpea Bradyrhizobium, TAL 1148 (Nitragin 27A8; USDA 3100) and TAL 480 (USAB 67), recommended by the Nitrogen Fixation by Tropical Agricultural Legumes Project, University of Hawaii, Paia, Hawaii, USA, along with a commercial multistrain (Nitragin; LiphaTech, Inc., Milwaukee, WI) were used as inoculants. Inoculum was applied to seed by mixing $100 \mathrm{mg}$ of peat inoculum $\left(10^{9}\right.$ cells $\mathrm{g}^{-1}$ peat) with 10 legume seeds and allowing it to adhere with molasses. Seeds treated with only molasses served as controls.

A total of eight treatments, including two cultivars and four inoculum applications of each cultivar, were evaluated for the summer legume part of this experiment. Three additional pots per replicate were used as summer fallow treatments for the winter wheat part of the experiment and received 0,45 , and $90 \mathrm{~kg} \mathrm{~N} \mathrm{ha}^{-1}$ as urea each year about 4 weeks after planting wheat. All pots were arranged in a randomized complete block design with four replications.

Exactly 10 inoculated or uninoculated chickpea seeds were planted in each designated pot on July 30, 1992, July 11, 1993, and June 16, 1994. Occasional poor germination of the 'ICCV-2' chickpeas necessitated 5 to 10 additional seeds to be planted in some pots for this cultivar within a week of original seeding. Soil was fertilized each year with $40 \mathrm{~kg} \mathrm{P} \mathrm{ha}^{-1}$ as treble superphosphate. Plants were watered at least once every $2 \mathrm{~d}$ throughout the growing season. Air temperatures (Figure 1) were recorded at the Oklahoma Climatological Station located $37 \mathrm{~km}$ away. Seedlings were thinned to five plants per pot within 2 weeks of emergence. On three successive dates, one chickpea plant (roots and shoot) was removed; only the sample on the last date is reported here. Because year-to-year variation affected time of planting and harvest, the last chickpea

\footnotetext{
${ }^{1}$ The use of trade, firm, or corporation names in this publication is for the information and convenience of the reader. Such use does not constitute an official endorsement or approval by the authors, University of Central Oklahoma, or USDA Agricultural Research Service, of any product or service to the exclusion of others that may be suitable.
} 


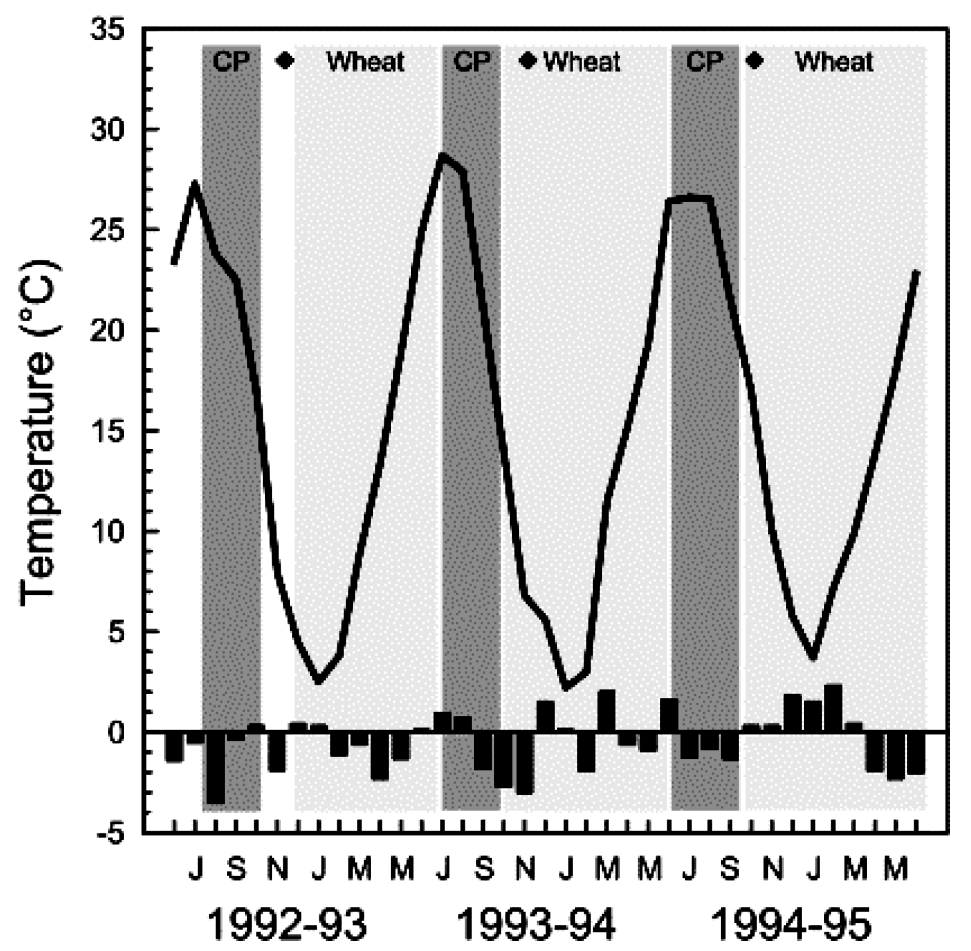

Figure 1. Average monthly air temperatures (solid line) and departures from normal (vertical solid bars) for the Oklahoma City weather station located $37 \mathrm{~km}$ from the experiment site. Vertical shaded bars represent growth duration of the chickpea (CP) and winter wheat (Wheat) crop rotations, and filled diamonds indicate sampling dates for soil cores.

harvest each year was 84 (22 October 1992), 88 (7 October 1993), and 98 (22 September 1994) d after planting (DAP). Whole plants were removed by excavating roots and soil in a $10-\mathrm{cm}$ core around the stem to the bottom of the pot. Roots and nodules were separated from plants and used to report results for nitrogen fixation (Bidlack et al., 2001). Any removed soil was discarded after shaking from roots and not returned to pots in order to avoid treatment contamination. Leaves, stems, and pods were separated and dried for $96 \mathrm{~h}$ at $40^{\circ} \mathrm{C}$ to obtain DW and to prepare for $\mathrm{N}$ determinations. Existing pods were removed after the last harvest from the remaining two plants and vegetative growth were chopped and incorporated into the top $10 \mathrm{~cm}$ of soil. Approximately 50 wheat seeds were then planted into each pot (including fallow treatments) on December 12, 1992, October 12, 1993, and October 1, 1994. All pots were watered to ensure hydration of seeds and incorporation of fertilizer into appropriate treatments. After germination, all treatments were thinned to 25 wheat seedlings per pot. 
Two soil cores $(2.5 \mathrm{~cm}$ diameter, $30 \mathrm{~cm}$ deep) taken from each pot within 4 weeks after wheat planting at 39, 48, and $35 \mathrm{~d}$ after harvesting chickpeas in 1992, 1993, and 1994, respectively, were immediately placed in a freezer at $-15^{\circ} \mathrm{C}$ for later analysis of mineral $\mathrm{N}$. Wheat plants were watered as needed until harvest at 210 (4 July 1993), 229 (7 June 1994), and 255 (22 June 1995) DAP. The aboveground portion of mature wheat plants was clipped to a stubble height of $5 \mathrm{~cm}$. Stubble was incorporated into the soil with a hand trowel to a depth of $10 \mathrm{~cm}$ to prepare the soil bed for chickpea planting.

Dried plant parts, ground to pass through a 1-mm screen of an Udy Cyclone Mill (Udy Corp., Ft. Collins, CO), and composite soil core samples from each pot were used for $\mathrm{N}$ analyses. Total $\mathrm{N}$ concentration of plant material was determined by combustion analysis using a CHN-1000 analyzer (LECO Corp., St. Joseph, MO). Within 3 weeks of collecting soil cores, the frozen samples were thawed to room temperature $\left(\approx 23^{\circ} \mathrm{C}\right)$ and within $2 \mathrm{~h}$ extracted with $2 \mathrm{M}$ potassium chloride $(\mathrm{KCl})$. A micro-Kjeldahl steam distillation method was used to determine extracted ammonium $\left(\mathrm{NH}_{4}^{+}\right)-\mathrm{N}$ and nitrate $\left(\mathrm{NO}_{3}^{-}\right)-\mathrm{N}($ Bremner and Keeney, 1966).

Analysis of variance (ANOVA) was used to determine differences in measurements as affected by cultivar, inoculum, year, and interactions thereof, as well as fallow treatments. Statistical analyses were conducted separately for chickpea and wheat data because the wheat experiment included analyses of additional treatments. Because treatments were applied to the same pots (experimental unit) each successive year and randomization did not change, both data sets were analyzed by SAS PROC MIXED to take advantage of the repeated measure analysis this procedure offers (Littell et al., 1996; SAS Institute, 1998). In cases where ANOVAs suggested significant differences, a Tukey-Kramer mean separation test was used to reveal which values were different at the 0.05 probability level.

\section{RESULTS}

Chickpea pod DW as well as N contents of stem, shoot, and pods were significantly affected by cultivar (Table 1). Year significantly affected DW and $\mathrm{N}$ content in all components, whereas the cultivar $\mathrm{x}$ year interaction had significant differences for leaf, shoot, and pod DW as well as leaf, stem, shoot, and pod $\mathrm{N}$ content. Neither inoculum, nor any of the inoculum interactions thereof, significantly changed DW or N content measurements. Hence, only cultivar and year effects on chickpea DW and $\mathrm{N}$ content were evaluated using Tukey-Kramer mean separation tests.

No significant differences in total DW or total $\mathrm{N}$ content were detected among years or between chickpea cultivars (Table 2). However, occasional differences were detected in measurements among years and between chickpea cultivars for some specific plant parts. For instance, pod DW of 'ICCV-2' was 


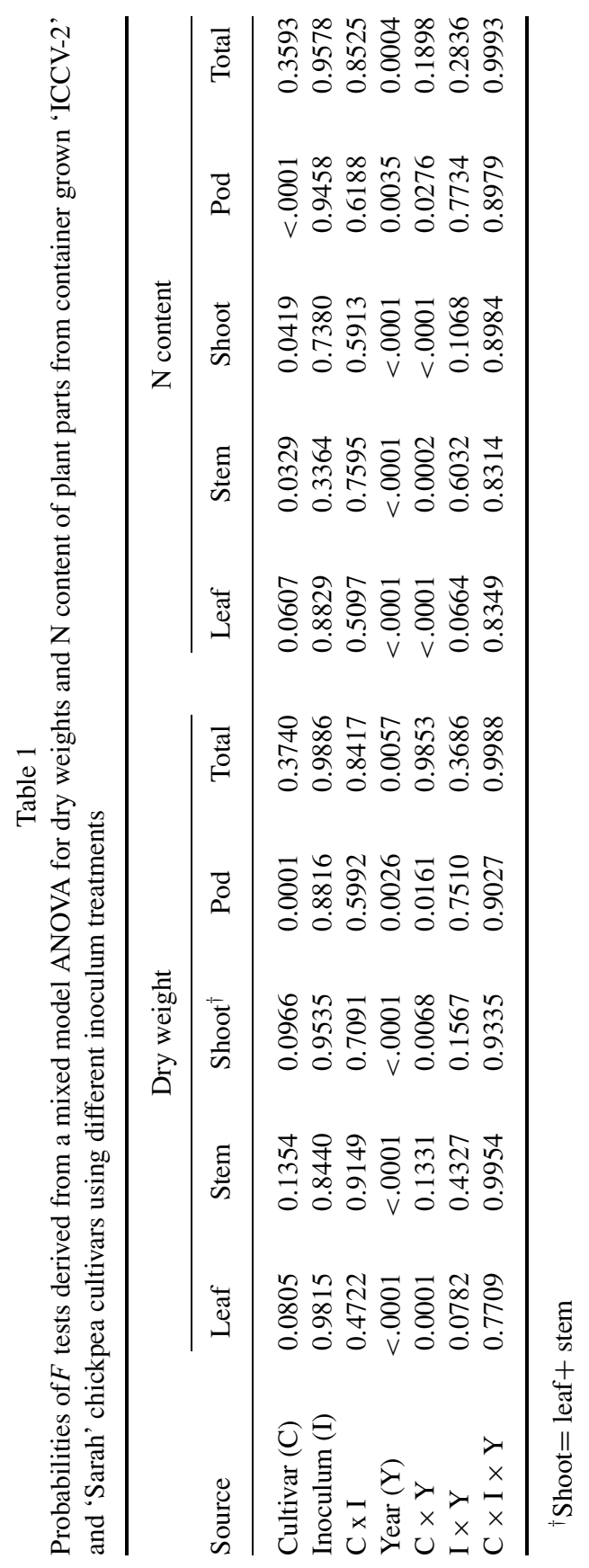




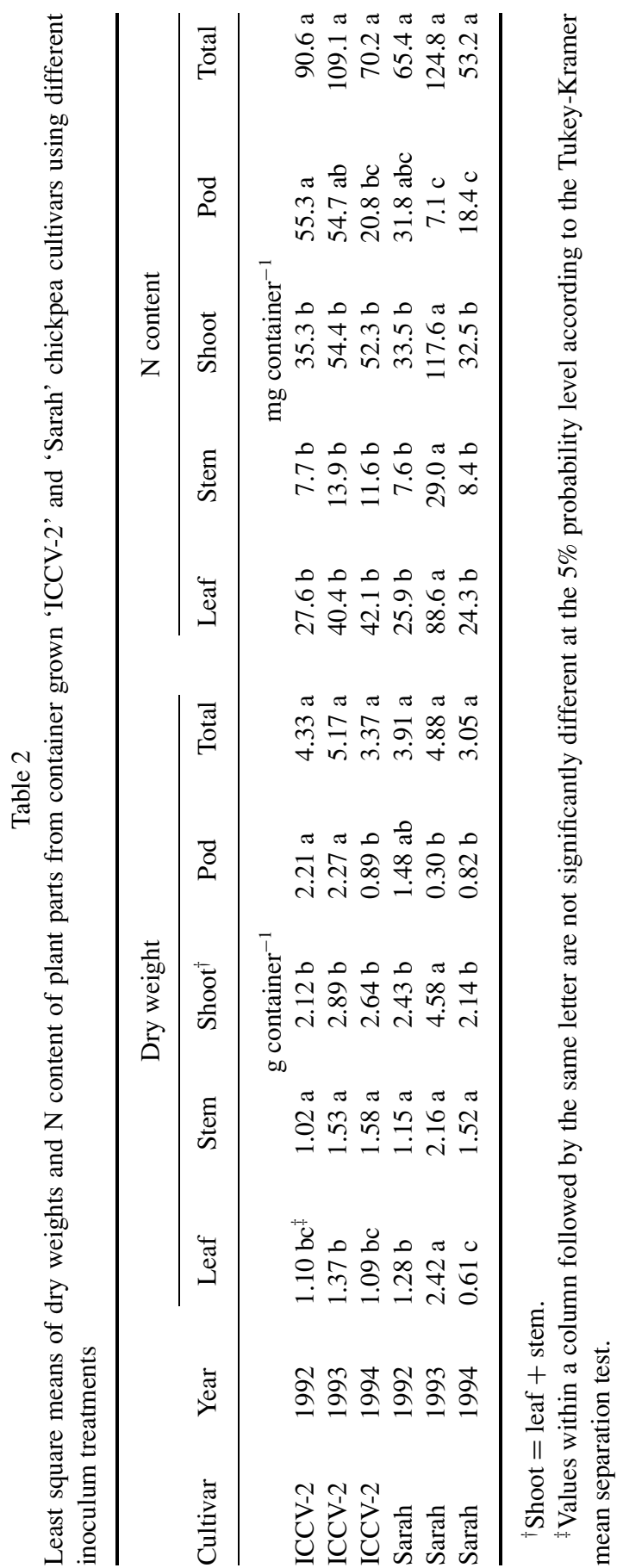


significantly greater in 1992 and 1993 compared with this same measurement in 1994; and pod N content of 'ICCV-2' was significantly greater in 1992 than it was in 1994. Each year the 'ICCV-2' chickpea cultivar produced numerically greater pod DW and N content compared with 'Sarah' chickpea, although this difference was not always significant. However, 'Sarah' chickpeas usually produced the same or more shoot DW and N content compared with these same measurements in the 'ICCV-2' cultivar. This was particularly evident in 1993 when the 'Sarah' cultivar had about twice as much leaf DW and N content than 'ICCV-2' produced in any year.

Measurements following chickpea harvests revealed some significant differences in soil mineral N, wheat DW, and wheat accumulated N (Table 3). Treatment (which included three fallow wheat treatments as well as wheat following chickpea) caused significant differences in stem, head and total DW as well as $\mathrm{N}$ content of wheat. Year significantly affected most of these measurements, as well as soil $\mathrm{NH}_{4}^{+}, \mathrm{NO}_{3}^{-}$, and total mineral $\mathrm{N}$. The treatment $\mathrm{x}$ year interaction had no significant effect on any of these measurements. Hence, treatment effects on wheat DW and accumulated $\mathrm{N}$ were evaluated, as well as year effects on soil nitrogen, through use of Tukey-Kramer mean separation tests.

Head and total DW of wheat following uninoculated or multistraininoculated 'Sarah' chickpea were significantly greater than head and total DW of wheat that remained fallow during the summer and received no $\mathrm{N}$ fertilizer (Table 4). Wheat DW of all other treatments was virtually the same except in one case where stem DW of wheat receiving $90 \mathrm{~kg} \mathrm{~N}^{-1}$ was greater than that of wheat receiving no $\mathrm{N}$ fertilizer. Similarly, total $\mathrm{N}$ accumulated by wheat following all 'Sarah' chickpea treatments was significantly more than $\mathrm{N}$ accumulated by wheat grown in pots that remained fallow during the summer and received no $\mathrm{N}$ fertilizer. Head $\mathrm{N}$ accumulated by wheat following uninoculated or multistrain-inoculated 'Sarah' chickpeas was more than that of wheat that remained fallow during the summer and received no $\mathrm{N}$ fertilizer. Stem, head, and total $\mathrm{N}$ accumulated by wheat in other treatments were essentially the same except in one case where stem $\mathrm{N}$ content of wheat receiving $90 \mathrm{~kg} \mathrm{~N} \mathrm{ha}^{-1}$ was greater than that of wheat receiving no $\mathrm{N}$ fertilizer.

When averaged across treatments, soil mineral $\mathrm{N}$ concentrations at 4 weeks after planting wheat were consistently low, but increased significantly during the last year (Table 5). Total soil mineral $\mathrm{N}$ followed this same trend and nearly tripled during the last year of the experiment. Wheat DW fluctuated slightly across years, as noted by significantly greater head and total wheat DW in 1993 compared with 1992 and 1994. Stem, head, and total N accumulation in wheat were significantly greater in 1993 and 1994, as evidenced by significantly more stem $\mathrm{N}$ in 1994 and the most total $\mathrm{N}$ accumulated in 1993 and 1994. 


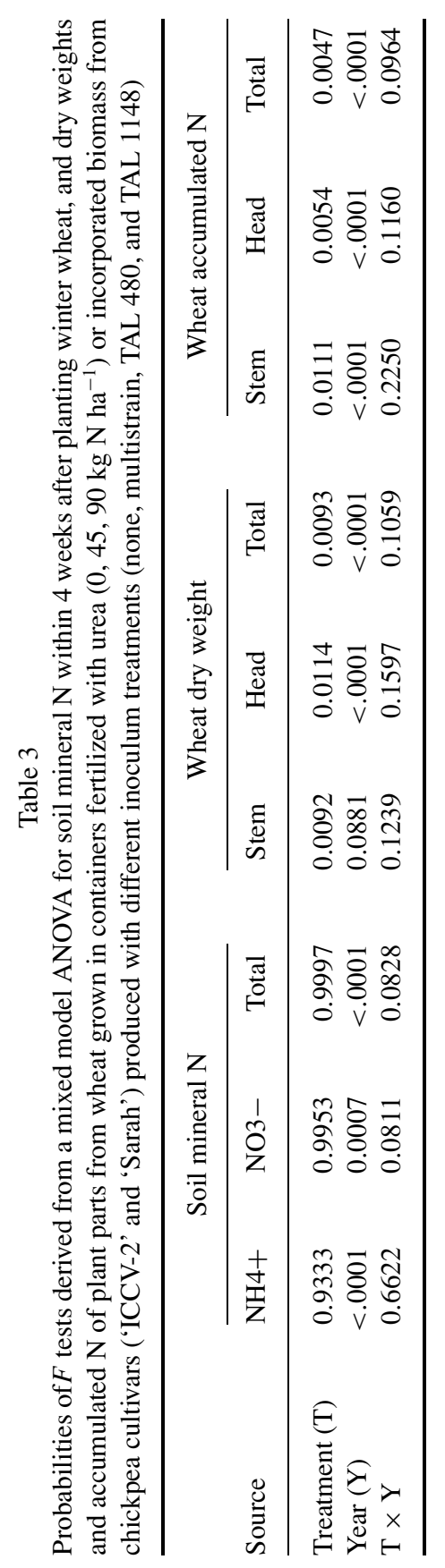


Table 4

Least square means of dry weights and accumulated $\mathrm{N}$ of plant parts from winter wheat grown after legumes or summer fallow in containers fertilized with urea or incorporated biomass from chickpea; data are averages across three consecutive years

\begin{tabular}{|c|c|c|c|c|c|c|c|}
\hline \multirow[b]{2}{*}{ Treatment } & \multirow[b]{2}{*}{ Inoculum } & \multicolumn{3}{|c|}{ Wheat dry weight } & \multicolumn{3}{|c|}{ Wheat accumulated $\mathrm{N}$} \\
\hline & & Stem & Head & Total & Stem & Head & Total \\
\hline & & \multicolumn{3}{|c|}{ g container ${ }^{-1}$} & \multicolumn{3}{|c|}{ mg container ${ }^{-1}$} \\
\hline \multicolumn{8}{|l|}{ Fertilizer } \\
\hline $0 \mathrm{~kg} \mathrm{~N} \mathrm{ha}{ }^{-1}$ & - & $1.62 \mathrm{~b}^{\dagger}$ & $2.51 \mathrm{~b}$ & $4.12 \mathrm{~b}$ & $7.9 \mathrm{~b}$ & $38.5 \mathrm{~b}$ & $46.3 \mathrm{~b}$ \\
\hline $45 \mathrm{~kg} \mathrm{~N} \mathrm{ha}^{-1}$ & 一 & $2.45 \mathrm{ab}$ & $3.33 \mathrm{ab}$ & $5.78 \mathrm{ab}$ & $14.7 \mathrm{ab}$ & $52.4 \mathrm{ab}$ & $67.1 \mathrm{ab}$ \\
\hline $90 \mathrm{~kg} \mathrm{~N} \mathrm{ha}^{-1}$ & - & $3.35 \mathrm{a}$ & $3.85 \mathrm{ab}$ & $7.18 \mathrm{ab}$ & $20.3 \mathrm{a}$ & $57.8 \mathrm{ab}$ & $77.4 \mathrm{ab}$ \\
\hline \multicolumn{8}{|l|}{ Chickpea } \\
\hline 'ICCV-2' & None & $1.86 \mathrm{ab}$ & $2.89 \mathrm{ab}$ & $4.73 \mathrm{ab}$ & $13.2 \mathrm{ab}$ & $55.1 \mathrm{ab}$ & $68.3 \mathrm{ab}$ \\
\hline 'ICCV-2' & multistrain & $1.89 \mathrm{ab}$ & $3.43 \mathrm{ab}$ & $5.32 \mathrm{ab}$ & $11.9 \mathrm{ab}$ & $66.2 \mathrm{ab}$ & $78.1 \mathrm{ab}$ \\
\hline 'ICCV-2' & TAL 480 & $2.09 \mathrm{ab}$ & $3.62 \mathrm{ab}$ & $5.70 \mathrm{ab}$ & $13.3 \mathrm{ab}$ & $66.2 \mathrm{ab}$ & $79.5 \mathrm{ab}$ \\
\hline 'ICCV-2' & TAL 1148 & $2.09 \mathrm{ab}$ & $3.61 \mathrm{ab}$ & $5.70 \mathrm{ab}$ & $11.7 \mathrm{ab}$ & $70.1 \mathrm{ab}$ & $81.8 \mathrm{ab}$ \\
\hline 'Sarah’ & None & $3.04 \mathrm{ab}$ & $4.98 \mathrm{a}$ & $8.02 \mathrm{a}$ & $18.0 \mathrm{ab}$ & $85.6 \mathrm{a}$ & $103.6 \mathrm{a}$ \\
\hline ‘Sarah’ & multistrain & $2.93 \mathrm{ab}$ & $5.04 \mathrm{a}$ & $7.97 \mathrm{a}$ & $16.2 \mathrm{ab}$ & $87.6 \mathrm{a}$ & $103.7 \mathrm{a}$ \\
\hline 'Sarah' & TAL 480 & $2.46 \mathrm{ab}$ & $4.22 \mathrm{ab}$ & $6.68 \mathrm{ab}$ & $17.0 \mathrm{ab}$ & $78.4 \mathrm{ab}$ & $95.4 \mathrm{a}$ \\
\hline ‘Sarah’ & TAL 1148 & $2.63 \mathrm{ab}$ & $4.52 \mathrm{ab}$ & $7.15 a b$ & $17.6 \mathrm{ab}$ & $79.6 \mathrm{ab}$ & $97.2 \mathrm{a}$ \\
\hline
\end{tabular}

†Values within a column followed by the same letter are not significantly different at the $5 \%$ probability level according to the Tukey-Kramer mean separation test.

\section{DISCUSSION}

Cultivar and year significantly affected DW and N content of some plant parts, indicating that genotype, as well as environment and length of growing season

Table 5

Yearly least square means of soil mineral $\mathrm{N}$ within 4 weeks after planting winter, and dry weights and accumulated $\mathrm{N}$ of plant parts from winter wheat grown after legumes or summer fallow in containers fertilized with urea or incorporated biomass from chickpea

\begin{tabular}{|c|c|c|c|c|c|c|c|c|c|}
\hline \multirow[b]{2}{*}{ Year } & \multicolumn{3}{|c|}{ Soil mineral $\mathrm{N}$} & \multicolumn{3}{|c|}{ Wheat dry weight } & \multicolumn{3}{|c|}{ Wheat accumulated $\mathrm{N}$} \\
\hline & NH4+ & NO3- & Total & Stem & Head & Total & Stem & Head & Total \\
\hline & \multicolumn{3}{|c|}{$\mathrm{mg} \mathrm{N} \mathrm{kg}^{-1}$ soil } & \multicolumn{3}{|c|}{ g container $^{-1}$} & \multicolumn{3}{|c|}{ mg container $^{-1}$} \\
\hline 1992 & $2.33 \mathrm{~b}$ & $1.47 \mathrm{~b}$ & $3.83 \mathrm{~b}$ & $2.00 \mathrm{a}$ & $3.29 \mathrm{~b}$ & $5.29 \mathrm{~b}$ & $7.9 \mathrm{c}$ & $48.0 \mathrm{c}$ & $55.9 \mathrm{~b}$ \\
\hline 1993 & $1.66 \mathrm{c}$ & $2.06 \mathrm{~b}$ & $3.72 \mathrm{~b}$ & $2.64 \mathrm{a}$ & $5.07 \mathrm{a}$ & $7.71 \mathrm{a}$ & $11.8 \mathrm{~b}$ & $84.1 \mathrm{a}$ & $95.9 \mathrm{a}$ \\
\hline 1994 & $5.31 \mathrm{a}$ & $3.88 \mathrm{a}$ & $9.18 \mathrm{a}$ & $2.56 \mathrm{a}$ & $3.09 \mathrm{~b}$ & $5.65 \mathrm{~b}$ & $24.3 \mathrm{a}$ & $69.1 \mathrm{~b}$ & $93.4 \mathrm{a}$ \\
\hline
\end{tabular}

${ }^{\dagger}$ Values within a column followed by the same letter are not significantly different at the 5\% probability level according to the Tukey-Kramer mean separation test. 
(see Figure 1), were important factors affecting chickpea growth in this experiment. However, varying inoculum strains or even withholding application of Bradyrhizobium inoculants had no effect on chickpea DW or $\mathrm{N}$ content. These results suggest that, for this investigation, selection of an appropriate cultivar and year-to-year variations are more important than inoculants in affecting chickpea DW and $\mathrm{N}$ content. These results partially agree with other studies demonstrating that both cultivar and inoculum strain influence yield of chickpeas (Somasegaran et al., 1988; Beck, 1992). Similar studies with chickpeas have shown that multistrain formulations were either as good as the most effective single-strain inoculants or intermediate between the most and least effective (Somasegaran and Bohlool, 1990). Perhaps in this investigation, native soil nodulating bacteria were competitive and/or prevalent enough to overshadow any inoculum effect. Previous studies with these same chickpea cultivars demonstrated similar results in that nodule count, nitrogenase activity, and nodule DW were minimally affected by inoculum treatment (Bidlack et al., 2001). However, these same studies revealed that 'Sarah' produced more nodules and had higher nodule DW than 'ICCV-2' chickpeas. The cultivars chosen ('ICCV-2' as a Kabuli-type chickpea and 'Sarah' as a Desi-type chickpea) were genetically different enough to reveal differences in the measurements obtained.

Even though 'Sarah' total DW was not significantly more than that of 'ICCV-2' chickpeas, shoot DW of 'Sarah' was either the same or greater than shoot DW of 'ICCV-2' during each year of the experiment. Moreover, pod DW of 'ICCV-2' was the same or greater than pod DW of 'Sarah' on an annual basis. This same trend was observed with $\mathrm{N}$ content of plant parts, whereby a greater amount of accumulated $\mathrm{N}$ in 'Sarah' was generally found in leaves and a greater amount of accumulated $\mathrm{N}$ in 'ICCV-2' was often found in pods. This was not surprising because the very early cultivar 'ICCV-2' flowered earlier (at about 35 d) than 'Sarah' (at greater than $50 \mathrm{~d}$ ) and clearly matured earlier. Hence, 'Sarah' accumulated more biomass in vegetative shoot components (leaf and stem) and 'ICCV-2' partitioned more photosynthate into reproductive structures (pods).

Wheat DW and $\mathrm{N}$ accumulation following chickpeas were either the same or greater than these same traits in wheat that received some or no $\mathrm{N}$ fertilizer. In particular, head and total wheat DW following two 'Sarah' chickpea treatments were significantly greater than these measurements in fallow wheat that received $0 \mathrm{~kg} \mathrm{~N} \mathrm{ha}^{-1}$. This same trend was observed for head and total $\mathrm{N}$ content of wheat in that, twice as much $\mathrm{N}$ accumulated in two treatments following 'Sarah' chickpeas compared with fallow wheat that received $0 \mathrm{~kg} \mathrm{~N}^{-1}$. These results demonstrate direct DW and $\mathrm{N}$ accumulation benefits to wheat following 'Sarah' chickpeas.

Interestingly, wheat DW and $\mathrm{N}$ accumulation following 'ICCV-2' chickpeas were not significantly greater than fallow wheat receiving $0 \mathrm{~kg} \mathrm{~N}^{-1}$, but also not significantly different from these measurements for wheat receiving 45 and $90 \mathrm{~kg} \mathrm{~N} \mathrm{ha}^{-1}$. This may be due to removal of pods in 'ICCV-2' each year, which could have provided residual nitrogen for wheat following chickpeas. 
Conversely, DW and N content of wheat following 'Sarah' chickpeas were always greater than those of 'ICCV-2,' although not significant for individual plant parts or total measurements. These observations were particularly true for DW and N content of wheat following 'Sarah' chickpeas that received multistrain or no inoculum treatments, which reinforced results for shoot DW and $\mathrm{N}$ content of chickpea plants during the summer.

Total soil mineral $\mathrm{N}$ did not change significantly the first two years of this experiment, but was about 2.4-fold greater the third year. While the benefit of soil $\mathrm{N}$ to wheat $\mathrm{DW}$ varied among years, $\mathrm{N}$ accumulated significantly in wheat during the last two years. These results support the potential for $\mathrm{N}$ contribution from fixation by chickpeas to winter wheat and the potential for this legume to increase DW and/or $\mathrm{N}$ accumulation by winter wheat when crop rotation is implemented.

\section{ACKNOWLEDGMENTS}

This project was funded by the USDA National Research Initiative Competitive Grants Program (Grant No. 93-37311-9580), Oklahoma Wheat Commission, University of Central Oklahoma (UCO) Office of Graduate Studies \& Research, and the USDA-ARS Grazinglands Research Laboratory. Authors thank members of the UCO Plant Physiology Research Group for assisting with the project.

\section{REFERENCES}

Auld, D. L., R. H. Callihan, G. A. Murray, L. E. O'Keeffe, and B. L. Bettis. 1982. Garbanzo beans-A potential new pulse crop for Idaho. Bull. No. 615. Moscow, ID: University of Idaho.

Beck, D. P. 1992. Yield and nitrogen fixation of chickpea cultivars in response to inoculation with selected rhizobial strains. Agronomy Journal 84:510-516.

Bidlack, J. E., S. C. Rao, and D. H. Demezas. 2001. Nodulation, nitrogenase activity, and dry weight of chickpea and pigeon pea cultivars using different Bradyrhizobium strains. Journal of Plant Nutrition 24:549-560.

Bremner, J. M., and D. R. Keeney. 1966. Determination and isotope-ratio analysis of different forms of nitrogen in soils: III. Exchangeable ammonium, nitrate, and nitrite by extraction-distillation methods. Soil Science Society of America Proceedings 30:577-582.

Kumar, J., M. P. Haware, and J. B. Smithson. 1985. Registration of four short duration fusarium wilt-resistant Kabuli (Garbanzo) chickpea germplasms. Crop Science 25:576-577.

Lal, R., E. Regnier, D. J. Eckert, W. M. Edwards, and R. Hammond. 1991. Expectations of cover crops for sustainable agriculture. In Cover crops 
for clean water, ed. W. L. Hargrove, 1-11. Ankeney, IA: Soil and Water Conservation Society.

Littell, R. C., G. A. Milliken, W. W. Stroup, and R. D. Wolfinger. 1996. SAS system for mixed models. Cary, NC: SAS Institute Inc.

McNew, K. 2001. Chickpeas: Production, uses, and exports. Briefing No. 19. Bozeman, MT: Montana State University.

Muehlbauer, F. J., and W. J. Kaiser. 1991. Registration of "Sarah" chickpea. Crop Science 31:1094.

SAS Institute. 1998. SAS/STAT user's guide release 7.00. Windows version 4.10.1998. Cary, NC: SAS Institute Inc.

Saxena, N. P. 1987. Screening for adaptation to drought: Case studies with chickpea and pigeon pea. 63-76. In ICRISAT (International Crops Research Institute for the Semi-Arid Tropics). Adaptation of Chickpea and Pigeonpea to Abiotic Stress: Proc. Consultants' Workshop. 19-21 Dec. 1984, 63-76. Patancheru, A.P., India.

Smith, V. H., and J. Jimmerson. 2005. Chickpeas (garbanzo beans). Briefing No. 55. Bozeman, MT: Montana State University.

Somasegaran, P., and B. B. Bohlool. 1990. Single-strain versus multistrain inoculation: Effect of soil mineral $\mathrm{N}$ availability on rhizobial strain effectiveness and competition for nodulation of chick-pea, soybean, and dry bean. Applied Environmental Microbiology 56:3298-3303.

Somasegaran, P., H. J. Hoben, and V. Gurun. 1988. Effects of inoculation rate, rhizobial strain competition, and nitrogen fixation in chickpea. Agronomy Journal 80:68-73. 